in vivo $35: 215-227(2021)$

doi:10.21873/invivo. 12250

\title{
Anti-metastatic Effects of Cationic KT2 Peptide (a Lysine/Tryptophan-rich Peptide) on Human Melanoma A375.S2 Cells
}

\author{
PORNSUDA MARAMING ${ }^{1}$, SOMPONG KLAYNONGSRUANG ${ }^{2}$, PATCHAREE BOONSIRI ${ }^{3}$, \\ SHU-FEN PENG ${ }^{4,5}$, SAKDA DADUANG ${ }^{6}$, PRAPENPUKSIRI RUNGSA ${ }^{6}$, \\ RATREE TAVICHAKORNTRAKOOL ${ }^{7}$, JING-GUNG CHUNG ${ }^{4 *}$ and JUREERUT DADUANG ${ }^{\text {* }}$ \\ ${ }^{1}$ Biomedical Science Program, Graduate School, Khon Kaen University, Khon Kaen, Thailand; \\ ${ }^{2}$ Protein and Proteomics Research Center for Commercial and Industrial Purposes (ProCCI), \\ Department of Biochemistry, Faculty of Science, \\ Khon Kaen University, Khon Kaen, Thailand; \\ ${ }^{3}$ Department of Biochemistry, Faculty of Medicine, Khon Kaen University, Khon Kaen, Thailand; \\ ${ }^{4}$ Department of Biological Science and Technology, China Medical University, Taichung, Taiwan, R.O.C.; \\ ${ }^{5}$ Department of Medical Research, China Medical University Hospital, Taichung, Taiwan, R.O.C.; \\ ${ }^{6}$ Division of Pharmacognosy and Toxicology, Faculty of Pharmaceutical Sciences, \\ Khon Kaen University, Khon Kaen, Thailand; \\ ${ }^{7}$ Centre for Research and Development of Medical Diagnostic Laboratories, \\ Faculty of Associated Medical Sciences, Khon Kaen University, Khon Kaen, Thailand
}

\begin{abstract}
Background/Aim: KT2 is a lysine/tryptophan-rich peptide modified from Crocodylus siamensis Leucrocin I. In this study, we examined the cell toxicity, cellular uptake, antimigration and anti-invasion activities of KT2 in A375.S2 human melanoma cells. Materials and Methods: A375.S2 cells were treated with KT2 peptide and then we performed MTT assay, study of cellular uptake by a confocal microscope, wound healing assay, transwell migration/invasion assay, and evaluation of the expression of metastasis-associated proteins. Results: KT2 can be internalized through the plasma membrane and can slightly alter cell morphology, decrease
\end{abstract}

This article is freely accessible online.

*These Authors contributed equally to this work.

Correspondence to: Jureerut Daduang, Ph.D., Centre for Research and Development of Medical Diagnostic Laboratories, Faculty of Associated Medical Sciences, Khon Kaen University, Khon Kaen 40002, Thailand. Fax/Tel: +66 43202088, e-mail: jurpoo@kku.ac.th and Jing-Gung Chung, Ph.D., Department of Biological Science and Technology, China Medical University, No 91, Hsueh-Shih Road, Taichung 40402, Taiwan, R.O.C. Tel: +886 422053366 ext 8000, Fax: +886 422053764, e-mail: jgchung@ mail.cmu.edu.tw

Key Words: KT2 peptide, human melanoma A375.S2, anti-invasion, anti-migration. the percentage of viable cells and inhibit cell migration and invasion of A375.S2 cells in a dose-dependent manner. This peptide suppressed MMP-2 activity, as measured by gelatine zymography assay. The protein level of MMP-2 was decreased by KT2. KT2 also down-regulated metastasis pathway-related molecules, including FAK, RhoA, ROCK1, GRB2, SOS-1, pJNK, p-c-Jun, PI3K, p-AKT (Thr308), p-AKT (Ser473), p-p38, $M M P-9, N F-k B$, and $u P A$. Conclusion: These results indicate that KT2 inhibits the migration and invasion of human melanoma cells by decreasing MMP-2 and MMP-9 expression through inhibition of FAK, uPA, MAPK, PI3K/AKT NF-kB, and RhoA-ROCK signalling pathways. These findings suggest that KT2 deserves further investigation as an anti-metastatic agent for human melanoma.

Metastatic cancer, a major cause of cancer mortality, accounts for approximately $90 \%$ of cancer-related deaths (1). Metastasis is the spread of cancer cells to new areas in the body by detaching from the primary tumour, travelling through the blood circulatory and lymphatic systems, escaping an immune system, extravasating at the distant network of capillaries within a tissue, invading and proliferating in new organs (2). Treatment options for advanced cancer include local treatments (surgery, ablative techniques, radiotherapy) and systemic treatment (chemotherapy, drug-targeted therapy, drug-hormone therapy, and immunotherapy) $(1,3,4)$. Treatment choices depend on 
the primary cancer site and where it has spread. Local therapies only influence a certain part of the body, and these may be especially beneficial for cancer that remains limited to systemic treatment (5). However, most patients still have a poor prognosis after metastasis, and some patients cannot be cured (6). Therefore, they stop all treatment or receive some medications to relieve symptoms while maintaining their quality of life.

The number of new cases of melanoma and nonmelanoma skin cancer has been rising over recent decades (7). Melanoma develops from pigment-producing cells named melanocytes, which is one of the most aggressive cancers (8) that causes the majority of deaths in all skin cancers (9). When found early, melanoma patients require only surgery as the main treatment, but once cancer cells metastasize throughout other parts of the body, melanoma treatments still have limitations (10). For this reason, researchers have explored new therapies for providing hope, improving the survival rate, and curing patients.

Vast numbers of publications strongly suggest that peptides are advantageous for finding and developing new drugs. Peptides are highly selective, inexpensive to produce, and easy to modify to improve stability and biological activity; these special characteristics make them a therapeutic choice for cancer $(11,12)$. Therapeutic peptides for cancer treatment have been categorized into three main groups: (1) antimicrobial/pore-forming peptides, (2) cell-penetrating peptides and (3) tumour-targeting peptides (13). A large number of bioactive peptides contain specific kinds of amino acids and can be referred to as tryptophan-, proline-, cysteine-, arginine-, or lysine-rich $(14,15)$. These compositions affect cell membrane interactions, cell penetration, and cell-selective, antibacterial or anticancer activities (15-18). Some bioactive peptides, such as leucine/lysine-rich K6L9 peptide (19), CT20p peptide (20), and 9R-P201 peptide (21), have anti-metastatic effects.

KT2 (NGVQPKYKWWKWWKKWW-NH ${ }_{2}$ ), a cationic amphipathic peptide, has 17 amino acids, 53\% hydrophobic residues, and 7 positively charged residues. The first sevenamino acids constitute a naturally occurring Crocodylus siamensis leucocyte peptide, which has antibacterial activity. To enhance the antibacterial effect, the hydrophobic amino acid tryptophan (W) was added to expand the hydrophobic region, and lysine $(\mathrm{K})$ was used to increase the hydrophilic part and charge (22). KT2 was found to inhibit the viability of cervical cancer HeLa cells (23) and induce apoptosis in colon cancer HCT-116 cells both in vitro and in vivo (24-26). Moreover, KT2 restrained the migration of HCT-116 cells (25). We hypothesized that cationic KT2 may have antimigration and anti-invasion activities against other types of cancer. Therefore, we investigated the anti-metastatic effects of KT2 on human melanoma A375.S2 cells and the related mechanisms of action.

\section{Materials and Methods}

Chemicals and reagents. KT2, a synthetic peptide generated by the Fmoc technique, was obtained from GL Biochem Ltd (Shanghai, China). Minimum essential medium (MEM), fetal bovine serum (FBS), and penicillin-streptomycin were purchased from Gibco Life Technologies, Inc. (Carlsbad, CA, USA). MTT (3-(4,5-dimethylthiazol2-yl)-2,5-diphenyltetrazolium bromide) was obtained from Invitrogen (Carlsbad, CA, USA). Primary antibodies, including anti-FAK, -Ecadherin, -SOS-1, -GRB2, -Snail, -PI3K, -p-AKT, and -NF-kB, were purchased from Cell Signaling Technology, Inc. (Beverly, MA, USA). Antibodies against VE-cadherin, vimentin, $\mathrm{p}$-c-Jun, and $\beta$-actin were purchased from Sigma Chemical Corporation (St. Louis, MO, USA). Anti-p-JNK, -MMP-2, -MMP-9, -RhoA, -ROCK1, -PKC, -uPA, -p-P38 antibodies and peroxidase-labelled antibodies were purchased from Santa Cruz Biotechnology (Santa Cruz, CA, USA).

Cell culture. A375.S2 human melanoma cells (The Food Industry Research and Development Institute, Hsinchu, Taiwan) were cultured in MEM supplemented with $10 \%$ FBS, 100 units/ml penicillin, and $100 \mu \mathrm{g} / \mathrm{ml}$ streptomycin at $37^{\circ} \mathrm{C}$ with a humidified atmosphere of $95 \%$ air and $5 \% \mathrm{CO}_{2}$

Cytotoxicity assay. To test the cytotoxic effect of KT2 on A375.S2 cells, $1 \times 10^{4}$ cells per well in $100 \mu \mathrm{l}$ complete medium, were seeded in a 96-well plate and treated with KT2 in $0.5 \%$ FBS-containing medium. After treatment, cell viability was determined by MTT assay. A $10-\mu 1$ solution of $5 \mu \mathrm{g} / \mathrm{ml}$ MTT was added to each well for $3 \mathrm{~h}$ at $37^{\circ} \mathrm{C}$. The supernatant was then discarded, and $100 \mu \mathrm{l}$ DMSO was added to dissolve the purple formazan crystal. All treatment concentrations were repeated in three wells.

Cellular uptake of the KT2 peptide in A375.S2 cells. A375.S2 cells $\left(1 \times 10^{5}\right.$ cells $)$ were plated on sterile square cover glass slides in 6well plates for 2 days and treated with $2.5 \mu \mathrm{M}$ FITC-KT2 for $4 \mathrm{~h}$. The cells were rinsed 2 times with phosphate-buffered saline (PBS) and fixed in $4 \%$ formaldehyde for $15 \mathrm{~min}$ in the dark. Samples were mounted with a drop of mounting medium and observed under a fluorescence microscope (Carl Zeiss Optical, Chester, VA, USA).

Wound healing assay. A375.S2 cells $\left(2 \times 10^{5}\right.$ cells $)$ were plated in MEM supplemented with $10 \%$ FBS in 6-well plates for $48 \mathrm{~h}$ until full confluence. The cells were gently and slowly scraped with a $200 \mu \mathrm{l}$ pipette tip across the centre of the well and washed with serum-free medium to remove debris from the wells. Cells were treated with $2.5,5$, and $10 \mu \mathrm{M} \mathrm{KT} 2$ in $0.5 \%$ FBS-containing medium for 12 and $24 \mathrm{~h}$. Cells were photographed using a light microscope $(200 \times)$ with a digital camera at 0,12 , and $24 \mathrm{~h}$ after treatment. The area of wound closure in each picture was determined by using ImageJ software (NIH, Bethesda, MD, USA).

Cell migration and invasion assay. Transwell inserts with a pore size of $8 \mu \mathrm{m}$ used in a 24 -well plate (Millipore, Billerica, MA, USA) were coated with collagen for the cell migration assay andcoated with Matrigel for the invasion assay (collagen/Matrigel: $1 \mathrm{X}$ PBS 1:10) overnight. The lower chambers were added to $1 \mathrm{ml}$ of MEM containing $10 \%$ FBS. A375.S 2 cells $\left(4.5 \times 10^{4}\right.$ cells $)$ were seeded in the upper chamber and incubated in serum-free MEM with $0,2.5,5$, and $10 \mu \mathrm{M} \mathrm{KT} 2$. After $24 \mathrm{~h}$, cells were fixed with cold methanol and stained with crystal violet. Non-migratory cells 

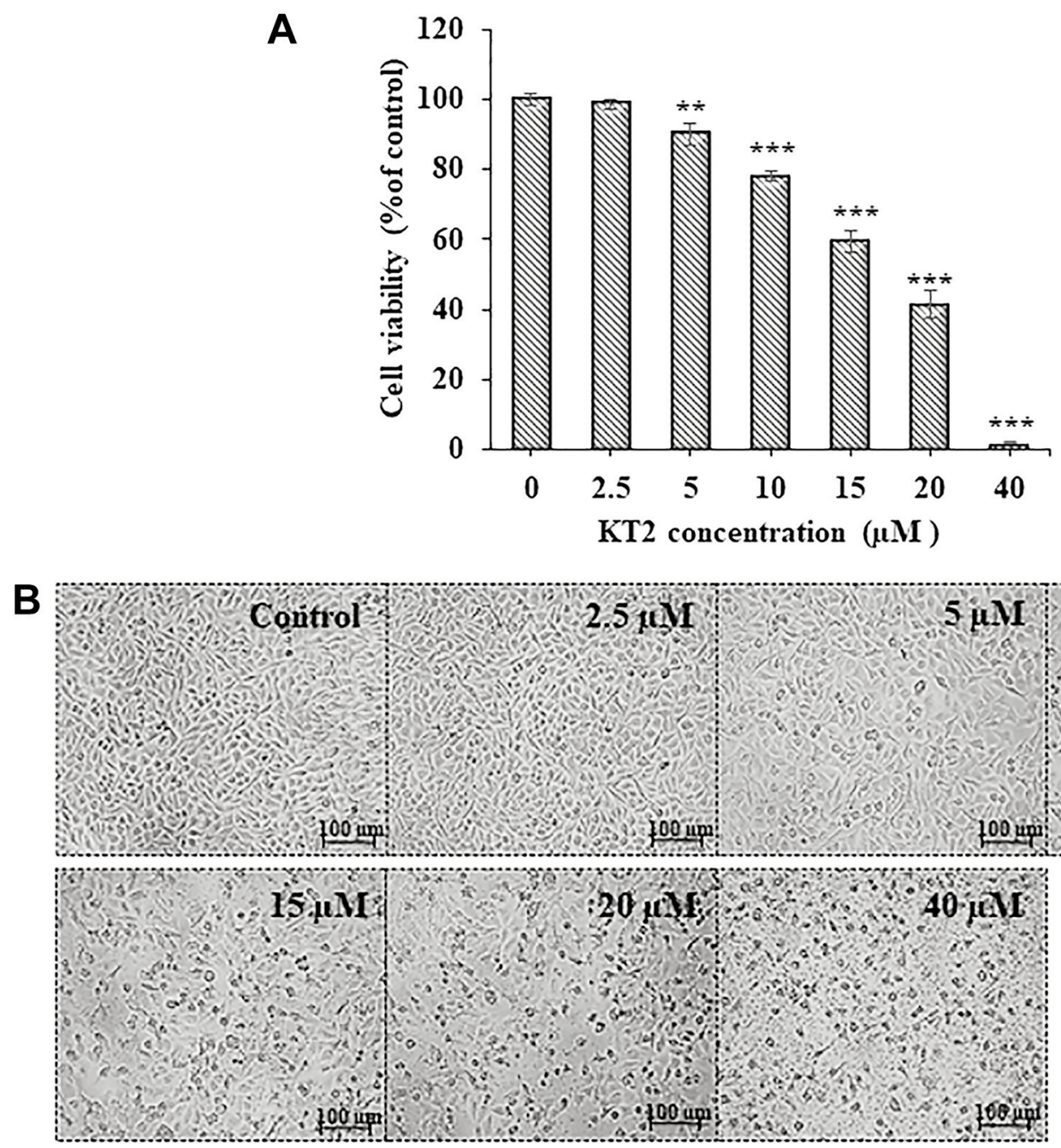

C

Control

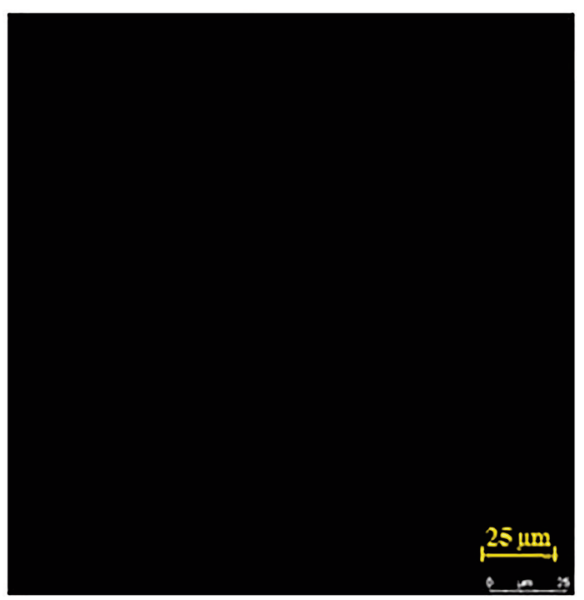

$\mathrm{KT} 2-2.5 \mu \mathrm{M}$

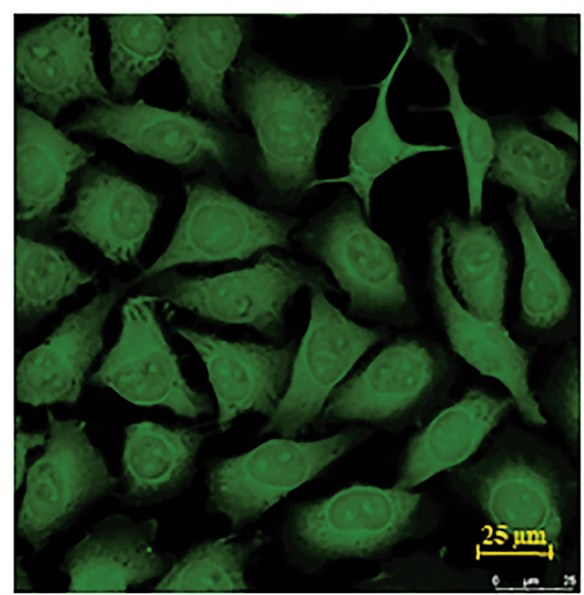

Figure 1. The viability and morphology of KT2-treated A375.S2 cells and the internalization of KT2. The cells $\left(1 \times 10^{4}\right.$ cells/well) were seeded and treated with KT2 at various doses $(0,2.5,5,10,20$, and $40 \mu \mathrm{M})$ for $24 \mathrm{~h}$. Cell viability was measured by the MTT assay, and the percentage of viable cells was calculated (A). Cell morphology of the treated cells at various doses of KT2 (B). The cells were treated with $2.5 \mu M$ fluorescein isothiocyanate (FITC)-labelled KT2, and samples were prepared as described in the Materials and Methods and photographed under a confocal microscope $(C) . * p<0.05, * * p<0.01, * * * p<0.001$. 
A

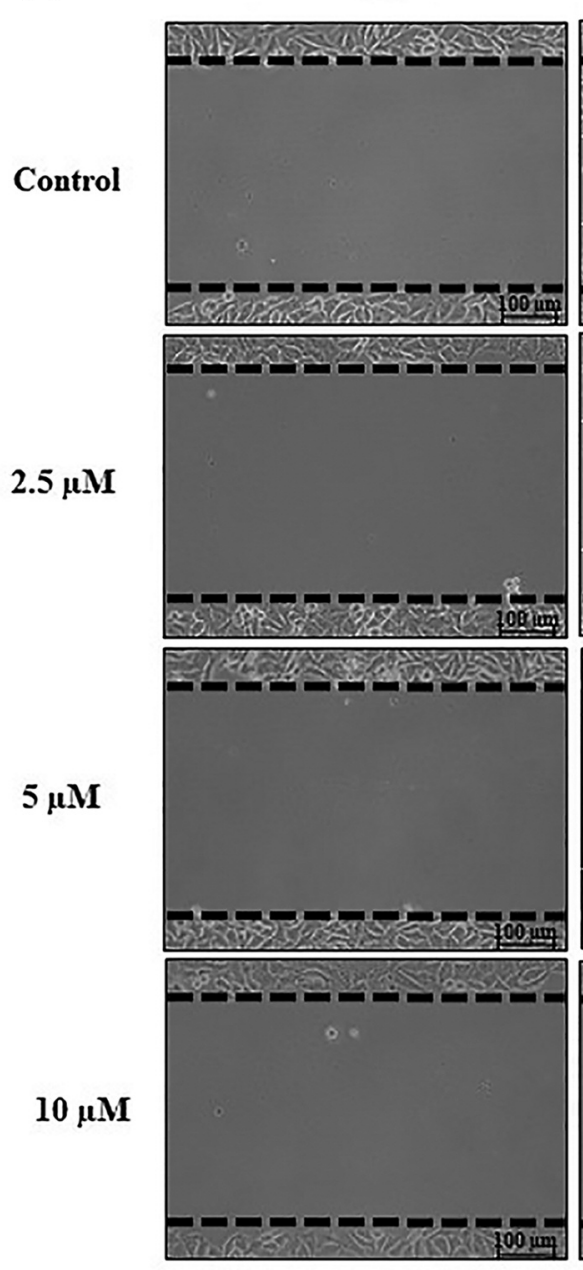

B
$12 \mathrm{~h}$
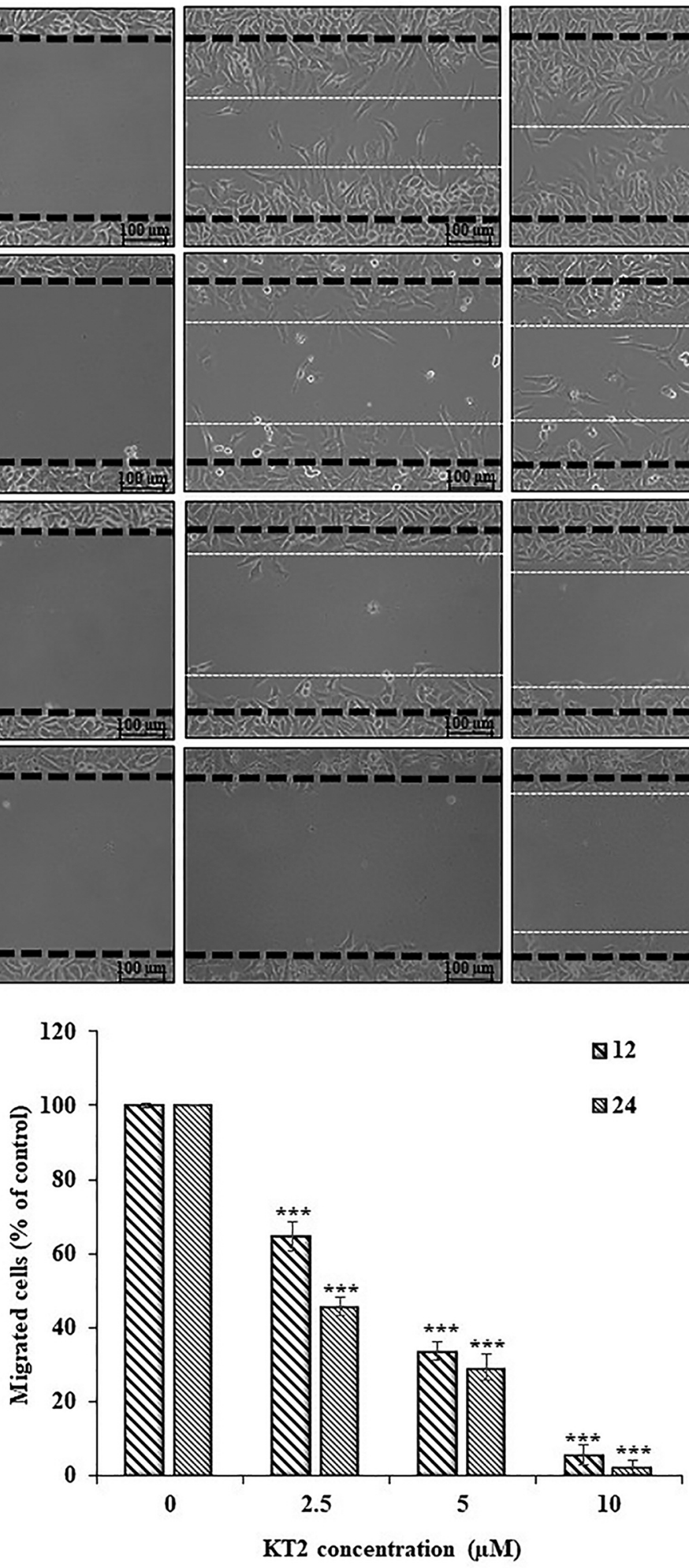

Figure 2. Scratch wound healing assay. Cells $\left(2 \times 10^{5}\right.$ cells/well $)$ in MEM supplemented with 10\% FBS were plated into 6-well plates for $48 \mathrm{~h}$ until full confluence. The cells were scraped with a $200 \mu \mathrm{l}$-pipette tip across the centre of the well and treated with 0, 2.5, 5.0, and $10 \mu \mathrm{M} \mathrm{KT2} \mathrm{in} \mathrm{0.5 \%}$ FBS-containing medium for 12 and 24 h. Cells were photographed using a light microscope (200x) with a digital camera at 0, 12, and 24 h after treatment. (A) The wound healing assay. (B) The rate of cell migration. $* * * p<0.001$. 


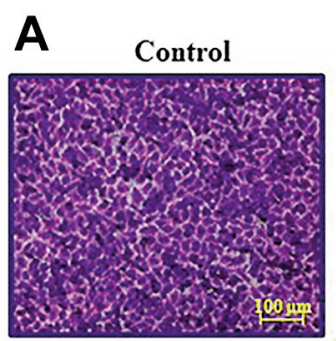

$5 \mu \mathrm{M}$
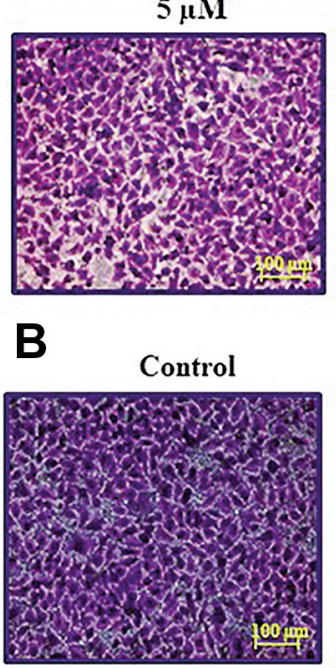

$5 \mu \mathrm{M}$

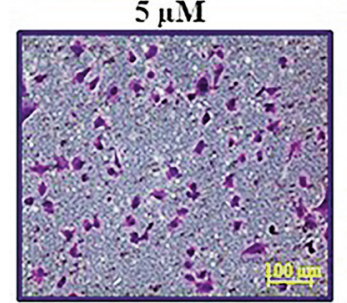

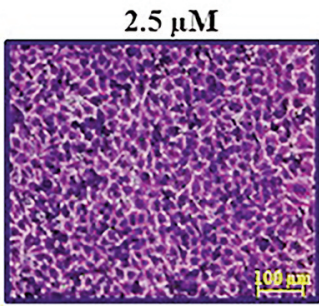

$10 \mu \mathrm{M}$

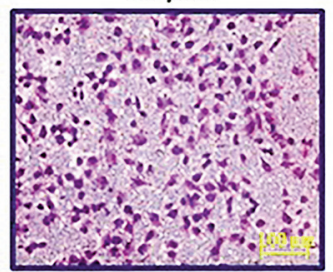

$2.5 \mu \mathrm{M}$

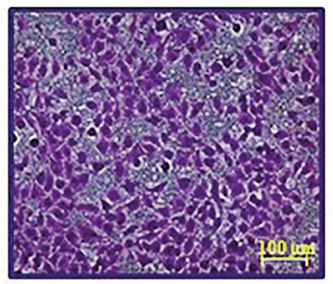

$10 \mu \mathrm{M}$

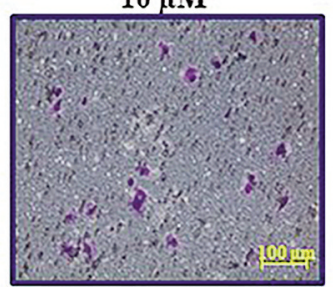

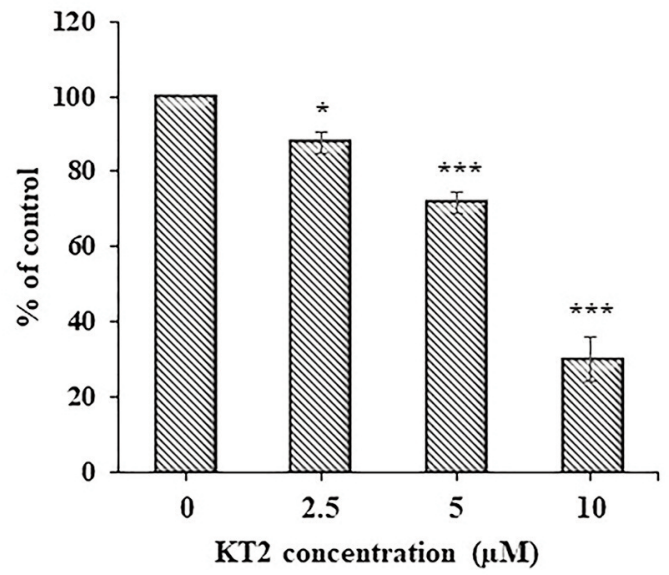

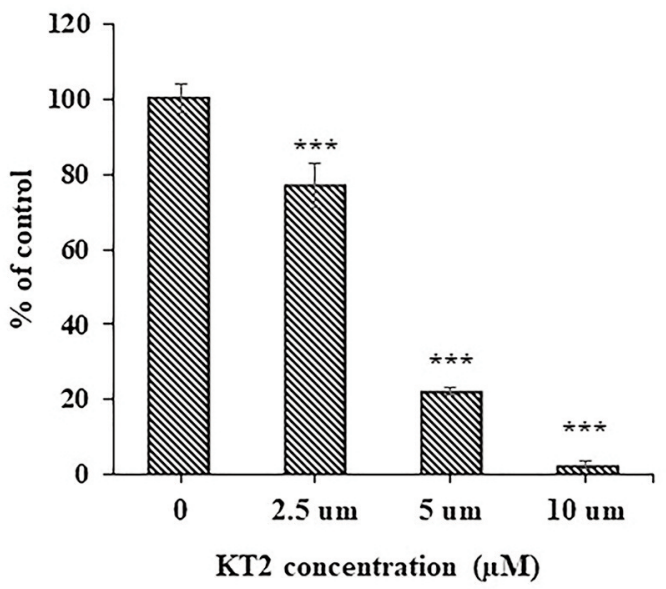

Figure 3. The rate of A375.S2 cell migration (A) and invasion (B). A375.S2 cells $\left(4.5 \times 10^{4}\right.$ cells/well) were seeded in the upper chamber-coated with collagen or Matrigel and were incubated in serum-free MEM with 0, 2.5, 5.0, or $10 \mu M$ KT2 for 24 h. Migratory or invasive cells were stained with crystal violet and photographed under a light microscope at $200 \times .{ }^{*} p<0.05$ and $* * * p<0.001$.

or non-invasive cells were removed with cotton swabs and photographed under a light microscope at $200 \times$. The pictures were analysed using ImageJ, and percentage inhibition was calculated based on total cell numbers in each picture (27).

Zymogram refolding gel assay. The experiment was carried out according to previous studies $(28,29)$ with slight modification. Sample preparation: The culture medium was collected after KT2 treatment and centrifuged at $13,000 \mathrm{rpm}$ for $5 \mathrm{~min}$ to remove cell debris. The supernatant was loaded into an $8 \%$ sodium dodecyl sulfate-polyacrylamide gel- $0.19 \%$ gelatine and run on 120 voltages at $4{ }^{\circ} \mathrm{C}$. The gel was washed with $2.5 \%$ (vol/vol) Triton $\mathrm{X}-100$ in double distilled water (DDW) for 15 min three times and incubated in the developing buffer $\left(0.05 \mathrm{M}\right.$ Tris-base, $0.01 \mathrm{M} \mathrm{CaCl}_{2}-2 \mathrm{H}_{2} \mathrm{O}$, $0.05 \mathrm{M} \mathrm{NaCl}$ and 5\% Brij V R 35 solution, $\mathrm{pH} \mathrm{7.6)} \mathrm{at} 37^{\circ} \mathrm{C}$ for 24 h. The gel was stained with Coomassie blue R-250 for $30 \mathrm{~min}$, incubated with a destaining solution (10\% acetic acid in $30 \%$ methanol in DDW), and washed with DDW. Clear bands indicating MMP-2 activity were seen.

Measurement of metastasis-associated protein expression by western blot analysis. A375.S2 cells $\left(1 \times 10^{6}\right.$ cells/dish $)$ were plated and treated with $\mathrm{KT} 2(2.5,5.0,10 \mu \mathrm{M})$ for $24 \mathrm{~h}$. After the indicated time, the cells were collected and washed once with PBS.PRO-PREP protein extraction solution (iNtRON Biotechnology, Seongnam, Gyeonggi-do, Korea) was added to the cell pellets according to the manufacturer's instructions. Total protein concentration was determined using the Bio-Rad Protein Assay kit (Bio-Rad, Hercules, CA, USA). which is based on the Bradford method. The same amount of protein in each sample was separated by $8-12 \%$ sodium dodecyl sulfate-polyacrylamide gel electrophoresis. Protein was transferred onto polyvinylidene difluoride membranes (Millipore, 
A

KT2 concentration $(\mu \mathrm{M})$

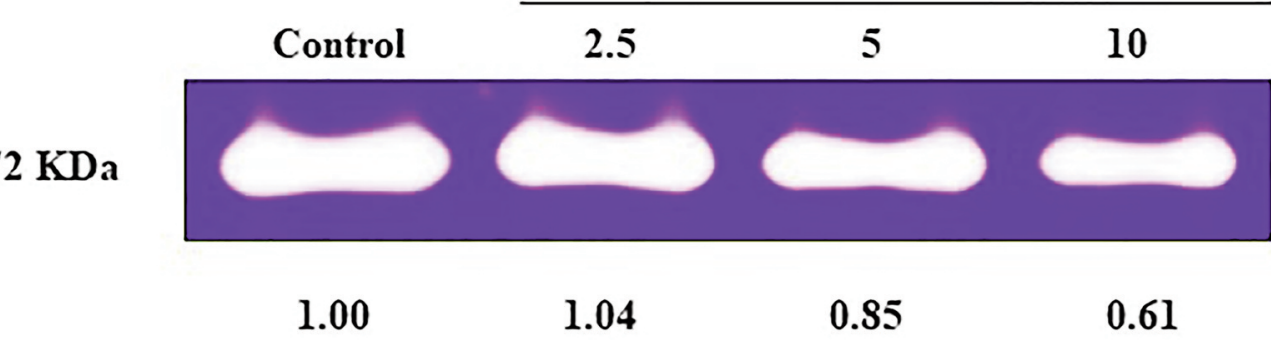

B KT2 concentration $(\mu \mathrm{M})$

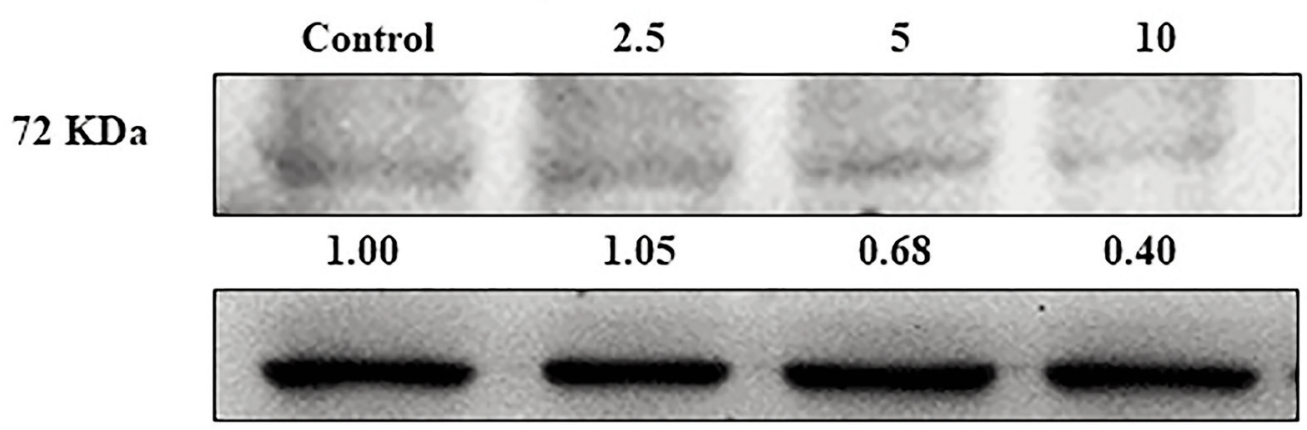

MMP-2

$\beta$-actin

Figure 4. The detection of MMP-2 activity and MMP-2 protein. A375.S2 cells were treated with 2.5-10 $\mu M$ KT2 for 24 h, media were collected to detect MMP activity by using gelatine zymography (A), and cells were harvested for western blot analysis (B).

Billerica, MA, USA). The membranes were blocked with $2 \%$ fetal bovine serum in PBST (0.1\% Tween-20 in $1 \mathrm{X}$ PBS, pH 7.4) for 1 $\mathrm{h}$. The membranes were incubated with primary antibodies (antiFAK, -p-JNK, -MMP-2, -MMP-9, -RhoA, -ROCK1, -SOS-1, GRB2, -p-c-Jun, -PI3K, p-AKT (Thr308), p-AKT (Ser473), -NF$\mathrm{KB}$, - $\mathrm{uPA},-\mathrm{p}-\mathrm{p} 38$, and $-\beta$-actin) overnight and then incubated with peroxidase-labelled secondary antibody. After washing steps, the membranes were incubated in ECL western blot analysis substrate (Bio-Rad, Hercules, CA, USA) and the protein bands were visualized in the dark.

Immunostaining of metastasis-related proteins. For the immunofluorescent staining of apoptosis-related proteins, A375.S2 cells $\left(1 \times 10^{5}\right.$ cells/well $)$ were plated onto cover slips in six-well plates and treated with $10 \mu \mathrm{M}$ KT2. Cells were washed with PBS and fixed in 3\% paraformaldehyde for $15 \mathrm{~min}$, washed with PBS, permeabilized with $0.1 \%$ Triton X-100 for $10 \mathrm{~min}$, and blocked with $2 \%$ FBS. After washing, the cells were incubated with specific primary antibodies at $4^{\circ} \mathrm{C}$ overnight and then with FITC-conjugated anti-mouse or antirabbit IgG antibody in the dark. Nuclei were stained with DAPI.

Statistical analysis. The results are presented as the mean \pm standard deviation. The student's $t$-test was used to compare data between two groups, one-way analysis of variance (ANOVA) in SPSS version 19.0 was used to measure statistically significant differences between the means of the control and KT2-treated groups $\left({ }^{*} p<0.05\right.$, $* * p<0.01, * * * p<0.001)$.

\section{Results}

Cell-penetrating KT2 reduces A375.S2 cell viability. Cationic KT2 at 5-40 $\mu \mathrm{M}$ decreased cell proliferation at $24 \mathrm{~h}(0 \mu \mathrm{M}$ : $100 \% \pm 1.84 ; 2.5 \mu \mathrm{M}: 98.64 \% \pm 1.52 ; 5 \mu \mathrm{M}: 90.14 \% \pm 3.29 ; 10$ $\mu \mathrm{M}: 77.99 \% \pm 1.41 ; 15 \mu \mathrm{M}: 59.47 \% \pm 3.26 ; 20 \mu \mathrm{M}: 41.22 \% \pm 4.00$; $40 \mu \mathrm{M}: 1.92 \% \pm 0.24$ ) (Figure 1A). However, KT2 at 2.5-10 $\mu \mathrm{M}$ slightly affected cell morphological changes, as shown in Figure 1B. The KT2 peptide was internalized in A375.S2 cells, as shown in Figure 1C.

KT2 impairs wound healing. The effect of cationic KT2 on A375.S2 cell migration was investigated using a wound healing assay (Figure 2A). After treatment for 24 h, KT2treated cells still exhibited wound gaps created by scratching, whereas cells without treatment migrated into the centre of the gap. KT2 peptide at 2.5-10 $\mu \mathrm{M}$ significantly suppressed the motility of A375.S2 cell population in a dose- and timedependent manner (Figure 2B).

KT2 diminishes A375.S2 Cell migration and invasion. The migration and invasion of A375.S2 cells were seeded in transwell chambers-coated with collagen or Matrigel. The migration rates (calculated as \% of control) were $87.79 \%$, 
A

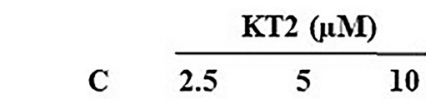

125

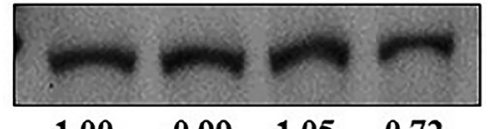

170

$$
\begin{array}{llll}
1.00 & 0.99 & 1.05 & 0.72
\end{array}
$$

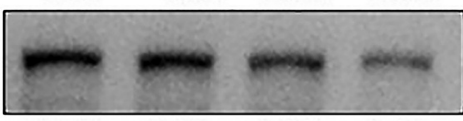

$$
\begin{array}{llll}
1.00 & 0.95 & 0.80 & 0.46
\end{array}
$$

24

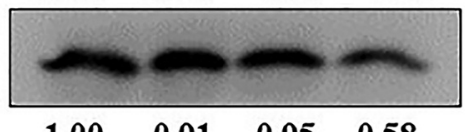

42

$$
\begin{array}{llll}
1.00 & 0.91 & 0.95 & 0.58
\end{array}
$$

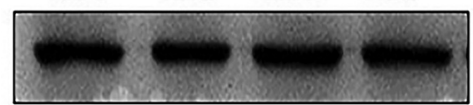

$\beta$-actin

C

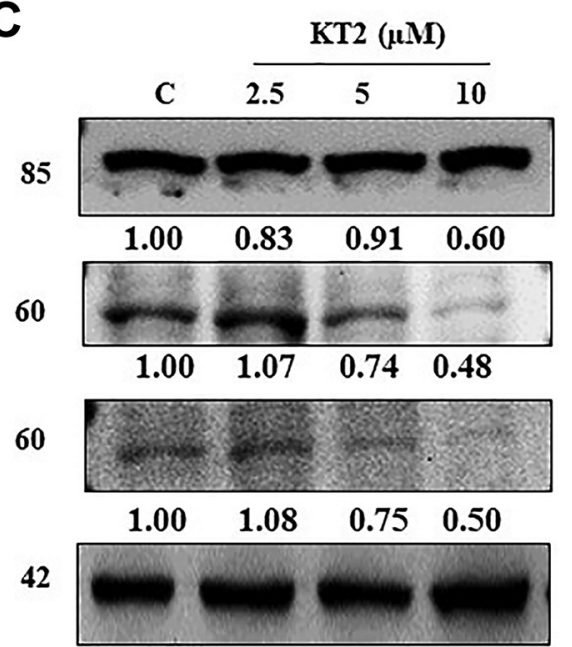

PI3K

p-AKT(Thr308)

p-AKT(Ser473)

$\beta$-actin
B
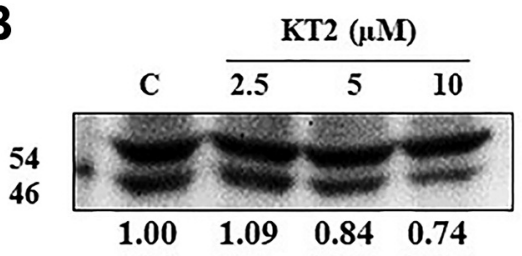

p-JNK p54 /p46

$\begin{array}{llll}1.00 & 1.01 & 0.78 & 0.45\end{array}$

65

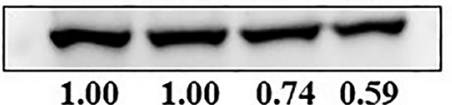

NF- $\mathrm{B}$

24

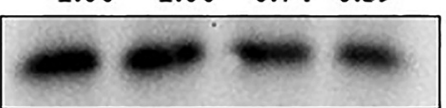

RhoA

42

$$
\begin{array}{llll}
1.00 & 1.17 & 0.81 & 0.63
\end{array}
$$

$\beta$-actin

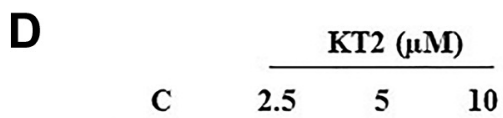

33

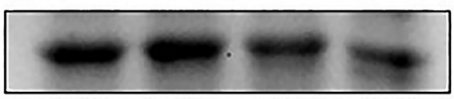

uPA

active enzyme

$$
\begin{array}{llll}
1.00 & 1.18 & 0.99 & 0.81
\end{array}
$$

39

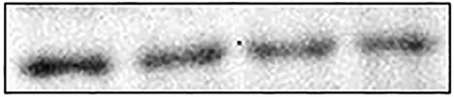

p-c-JUN

ROCK-1

160

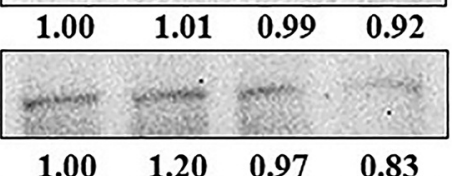

42

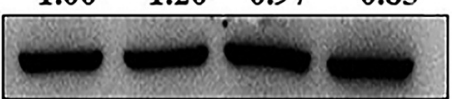

$\beta$-actin

E

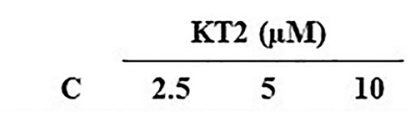

38

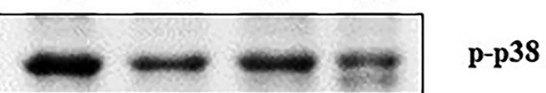

92

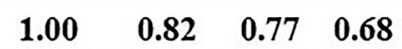

2

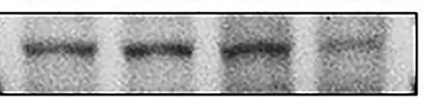

MMP-9

42
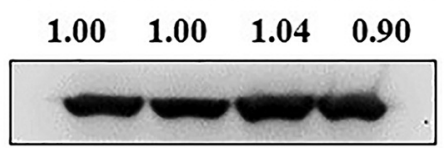

$\beta$-actin

Figure 5. KT2 affected the levels of metastasis-associated proteins in A375.S2 cells. The cells $\left(1 \times 10^{6}\right.$ cells/dish $)$ were treated with KT2 (0, 2.5, 5 , and $10 \mu \mathrm{M})$ for $24 \mathrm{~h}$. The cells were collected, and western blot analysis was performed as described in the Materials and Methods. The levels of FAK, SOS-1, and GRB2 (A), p-JNK, NF-kB and RhoA (B), PI3K, p-AKT (Thr308) and p-AKT (Ser473) (C), uPA, p-c-Jun, and ROCK-1 (D), p-p38 and MMP-9 (E), are shown. 
A
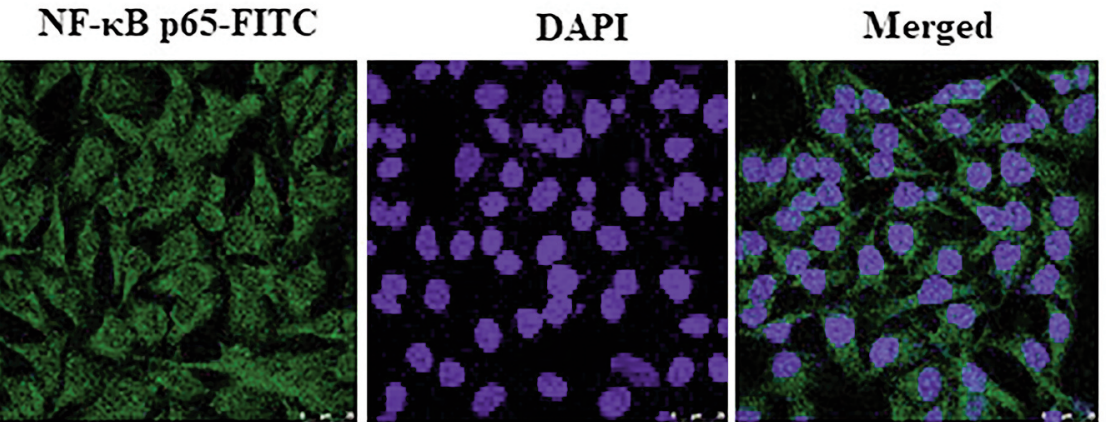

Control

$\mathrm{KT} 210 \mu \mathrm{M}$
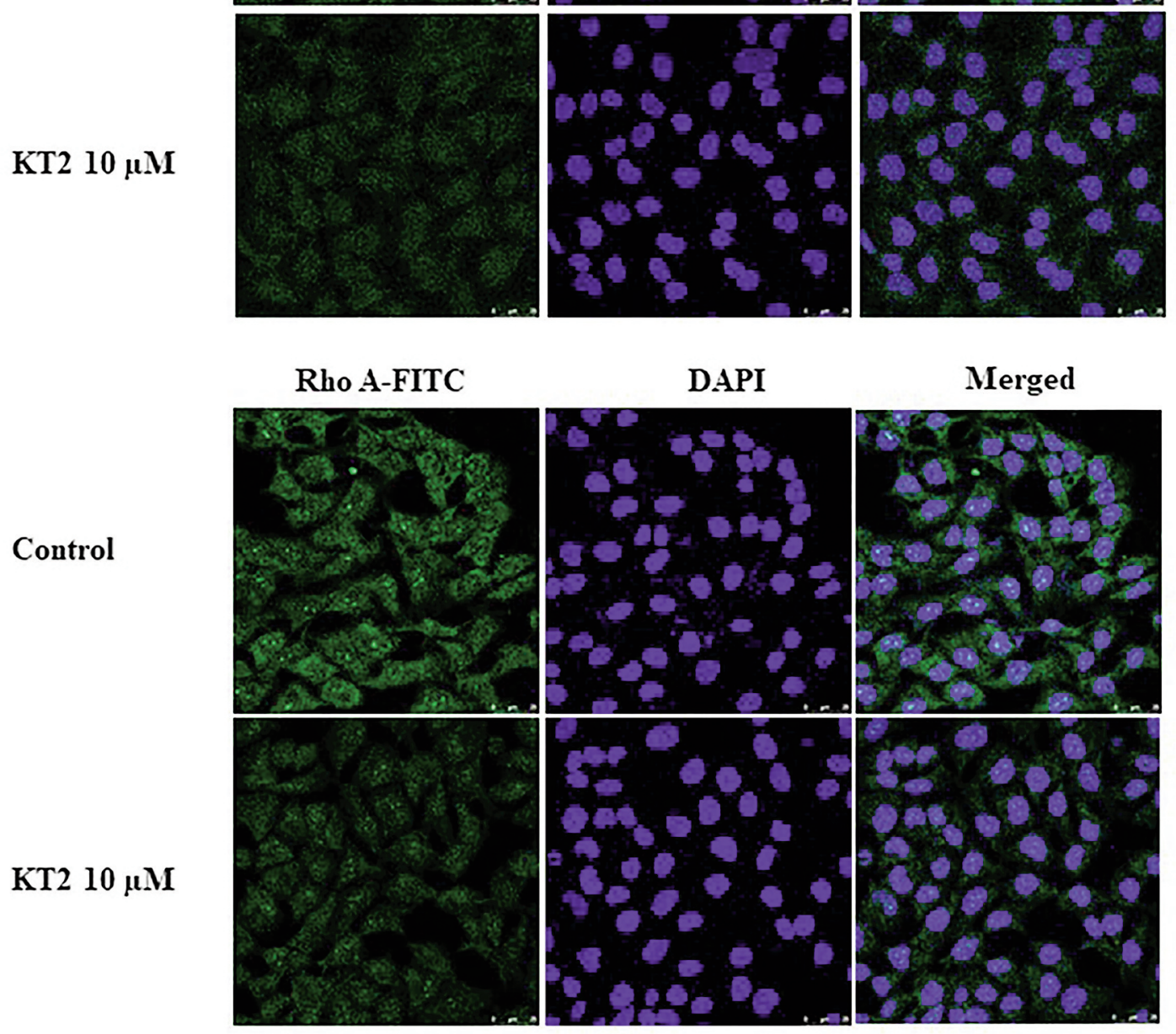

Figure 6. Continued

$71.79 \%$, and $30.21 \%$ after cells were treated with $2.5,5$, and $10 \mu \mathrm{M} \mathrm{KT} 2$ for $24 \mathrm{~h}$, respectively (Figure 3A). In Figure 3B, there were $76.88 \%, 22.15 \%$, and $2.87 \%$ invasion rates at $24 \mathrm{~h}$ after treatment with $\mathrm{KT} 2(2.5,5$, and $10 \mu \mathrm{M})$. In the presence of KT2 (2.5-10 $\mu \mathrm{M})$, A375.S2 cells suppressed cell migration and invasion in a dose-dependent manner at $24 \mathrm{~h}$.

KT2 decreases the activity and protein expression level of $M M P-2$. A zymogram refolding gel assay was used to analyse MMP-2 activity. After staining the gel, the results showed that
MMP-2 digested a protein substrate (gelatine) in the modified sodium dodecyl sulfate polyacrylamide gel electrophoresis protocol; the bands were approximately $72 \mathrm{kDa}$ in size, the molecular weight of MMP-2 (Figure 4A). MMP-2 activity was significantly inhibited by KT2 in a dose-dependent manner. Similarly, the protein expression levels of MMP-2 were reduced after KT2 treatment (Figure 4B).

KT2 alters metastasis-associated proteins. Our results showed that KT2 had anti-cell migration and anti-invasion 

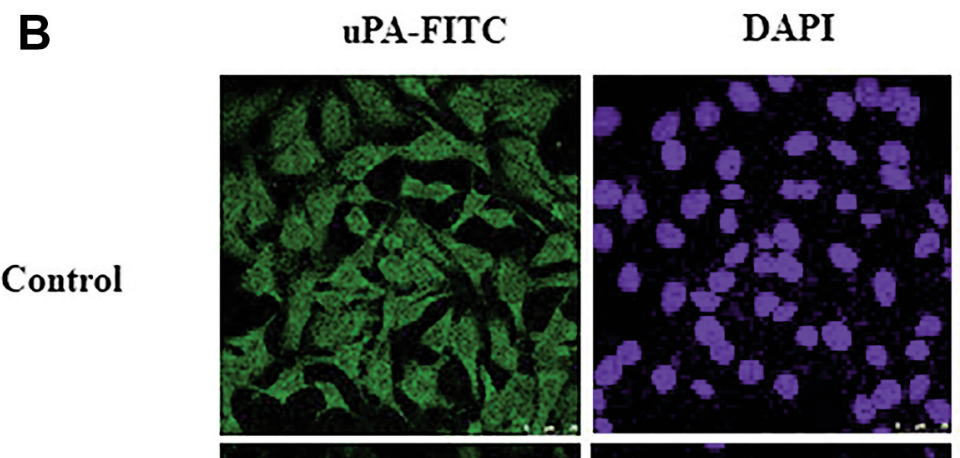

DAPI

\section{Control}

$\mathrm{KT} 210 \mu \mathrm{M}$

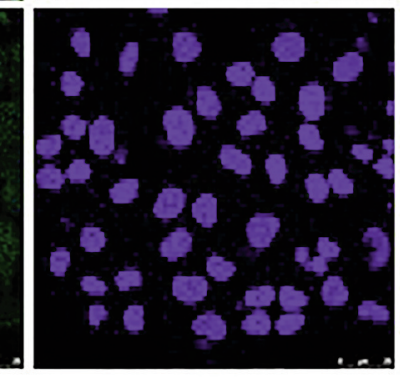

AKT308-FITC
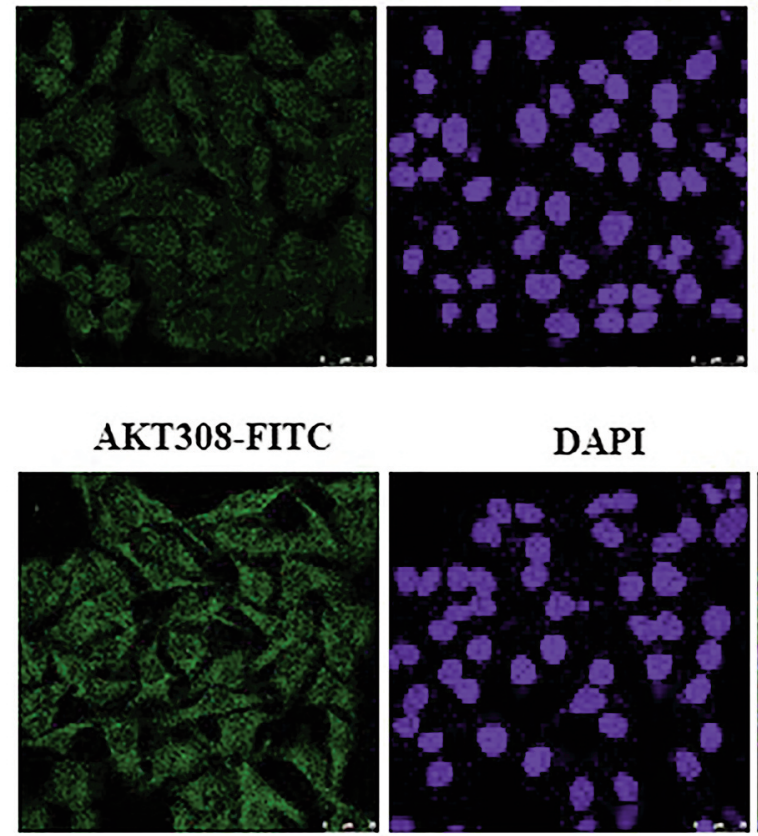

\section{DAPI}

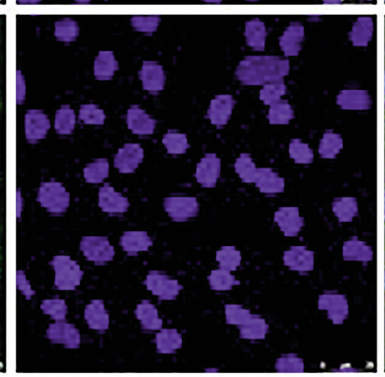

Merged
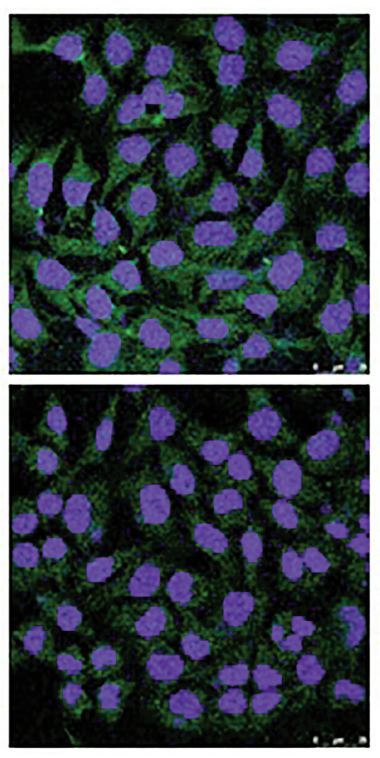

Merged
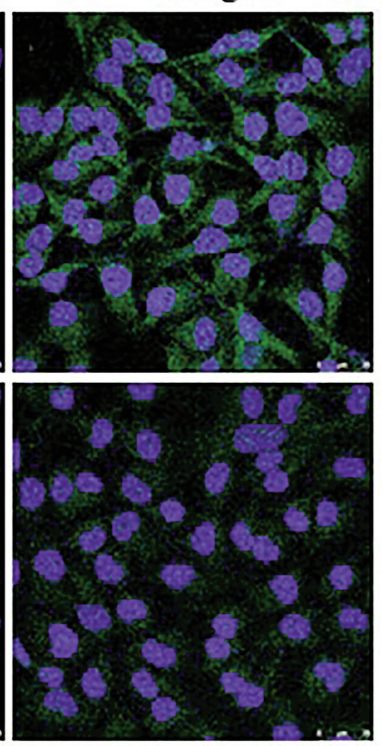

Figure 6. KT2 down-regulated the levels of NF-KB, RhoA, uPA, and p-AKT308 in A375.S2 cells. The cells $\left(1 \times 10^{5}\right.$ cells/well) were treated with 10 $\mu M K T 2$ for $24 \mathrm{~h}$. The cells were stained with primary antibodies and secondary antibodies (green signal). The nuclei were stained with DAPI (blue) as described in the Materials and Methods. The results showed the visualization of NF-kB and RhoA (A), uPA and p-AKT308 (B).

effects on A375.S2 cells. Therefore, we further examined whether KT2 suppressed cell metastasis via altered metastasis-associated proteins. The results showed that KT2 decreased the protein expression of FAK, SOS-1, and GRB2 (Figure 5A), p-JNK, NF-kB and RhoA (Figure 5B), PI3K, p-AKT (Thr308) and p-AKT (Ser473) (Figure 5C), uPA, p-c-Jun and ROCK-1 (Figure 5D), p-p38 and MMP9 (Figure 5E).
KT2 inhibits $N F-\kappa B$, RhoA, $u P A$, and p-AKT308 expression. To confirm the effect of KT2 on the expression of cancer metastasis-associated proteins, we assessed NF-kB, RhoA, uPA, and p-AKT308 protein levels by immunofluorescent staining; the stained samples were examined and photographed by confocal laser system microscopy. The results indicated that KT2 suppressed the protein expression of NF-kB, RhoA, uPA, and pAKT308 at $24 \mathrm{~h}$ (Figure 6). 


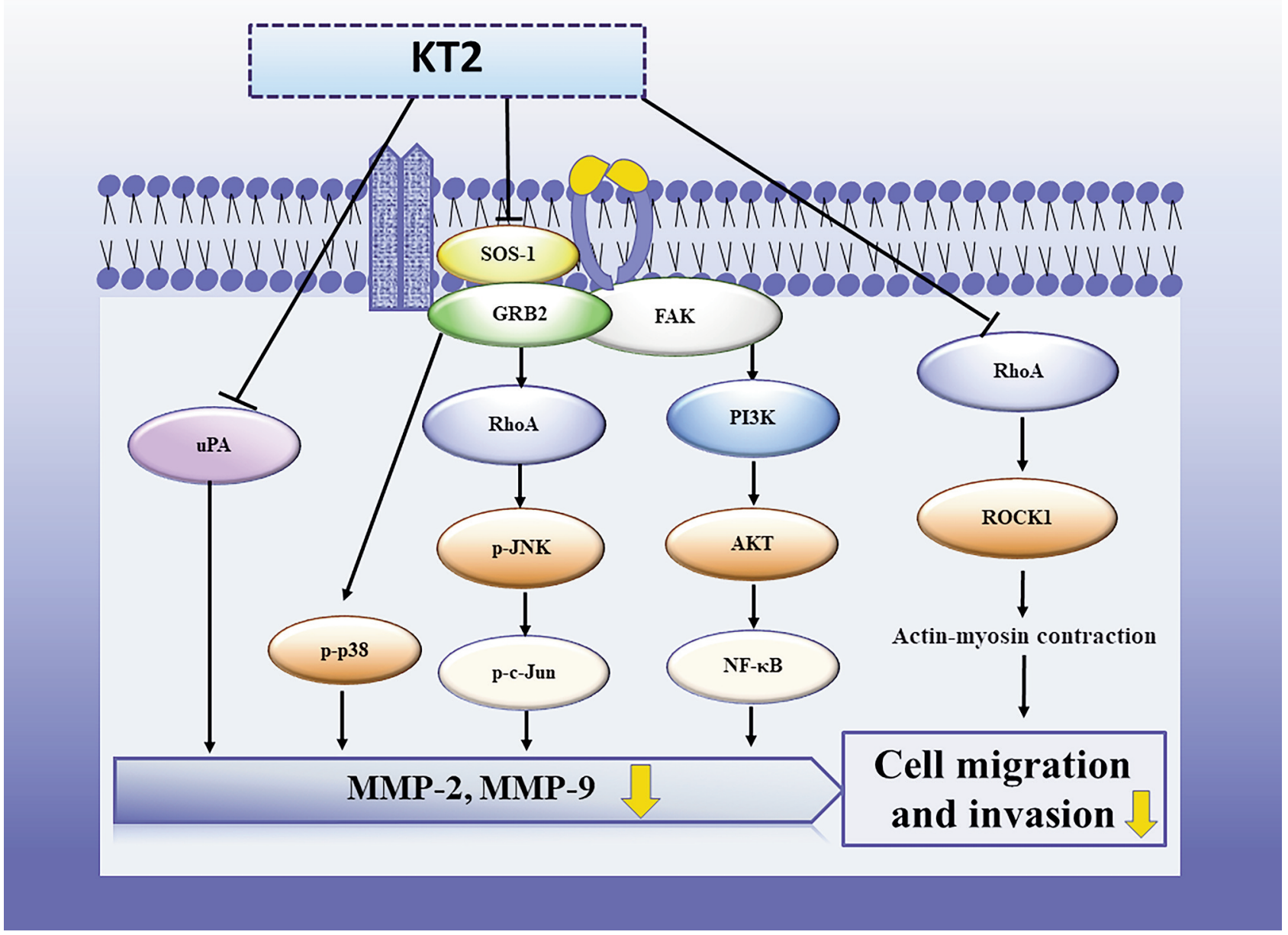

Figure 7. The possible signalling pathway for KT2-mediated suppression of A375.S2 cell migration and invasion in vitro.

\section{Discussion}

An important component of melanoma treatment is the capability to combat metastasis, which can improve longterm quality of life in patients. Most classical anticancer drugs are toxic against both cancerous and normal cells, thus leading to serious side-effects. Highly selective and more effective new drugs are urgently required to address this issue. In this context, bioactive peptides are being considered as good drug candidates for cancer therapy. Peptides for cancer therapy have been identified and developed for several decades, and they exhibit many different properties, such as selective membrane disruption, apoptosis induction, and anti-angiogenic and anti-metastatic activities (13, 30). These peptides target cancer cell membranes (31), the cell cytoskeleton (20) mitochondria (20), receptors (32), and intracellular biomolecules (DNA, RNA, or protein). However, the mode of action by which these bioactive peptides inhibit cancer cell proliferation and migration remains unclear.

A previous study showed that KT2 impaired the migration of HCT-116 colon cancer cells (25), but there is no report about the anti-metastasis effect of KT2 on A375.S2 human skin melanoma cells. Amphipathic cationic KT2 may be another possibility for the treatment of metastatic melanoma. To this point, we investigated whether KT2 could prevent metastatic cancer in human melanoma A375.S2 cells in vitro.

Lysine/tryptophan-rich KT2 (NGVQPKYKWWKWWKK $\mathrm{WW}-\mathrm{NH}_{2}$ ), an amphipathic cationic peptide, can be internalized into A375.S2 cells (Figure 1C). It is well known that arginine and lysine, positively charged amino acids, are involved in the cell surface binding and uptake of cellpenetrating peptides in mammalian cells (33). KT2 can also penetrate the bacterial membrane of Escherichia coli O157: $\mathrm{H} 7$ cells (34). A cell-penetrating peptide of KT2 may have cytotoxic activity and affect intracellular protein signalling 
pathways in human melanoma cells. Therefore, we examined the cytotoxicity of KT2 in A375.S2 cells in vitro. KT2 at concentrations of 5-40 $\mu \mathrm{M}$ significantly decreased A375.S2 cell growth at $24 \mathrm{~h}$ (Figure 1A), and KT2-treated cells slightly exhibited cell morphological changes (Figure 1B). However, KT2 was less cytotoxic to non-cancerous Vero cells and human red blood cells $(22,25)$. Three concentrations of KT2 $(2.5,5$, and $10 \mu \mathrm{M}$ ) were selected for further experiments because they led to a cell viability range of approximately $80-100 \%$.

The scratch wound healing assay was performed to study cell migration in vitro. The results showed that KT2 inhibited the migration of A375.S2 cells in a dose- and time-dependent manner (Figure 2) and correlated with the results of the transwell migration assay (Figure 3A). These results were in agreement with a recent study that KT2 restrained the cell mobility of human colon cancer HCT-116 cells compared to untreated cells in a dose-dependent manner (25). Moreover, KT2 suppressed cell invasion at 2.5-10 $\mu \mathrm{M}$ after 12 and 24 $\mathrm{h}$ of treatment (Figure 3B). Cell invasion requires matrix metalloproteinases (MMPs) to cleave extracellular matrix (ECM) components; therefore, cells penetrate through the ECM and travel to distant sites (35). MMP-2 activity was measured by gelatine zymography, and the results showed that 5 and $10 \mu \mathrm{M}$ KT2 significantly reduced MMP-2 activity after treatment for $24 \mathrm{~h}$ (Figure $4 \mathrm{~A}$ and B), which was confirmed by a decrease in MMP-2 protein (Figure 4C). MMP-2 is elevated in human cancers and associated with cancer invasion and angiogenesis (36). Therefore, the suppression of MMP-2 can prevent tumour cell metastasis.

Other metastasis-related proteins were also examined by western blot analysis (Figure 5) and imunofluorescence staining (Figure 6). Elevated expression of FAK, RhoA, and ROCK1 was found in cancer cells and is involved in metastasis and aggressive tumour growth (37-39). These proteins are an important target for metastatic cancer therapy. KT2 inhibited FAK, RhoA, and ROCK1 in A375.S2 cells. It is possible that KT2 interferes with the integrin signalling pathway involving FAK and A375.S2 cell migration and invasion were then inhibited. Furthermore, suppressed FAK cells inhibit cell proliferation and cell survival (28), leading to a reduced percentage of viable A375.S2 cells, as shown by the decreased protein expression levels of SOS-1 and GRB2, pJNK, p-c-Jun, p-p38, NF-kB, p-AKT (Thr308), and p-AKT (Ser473). These proteins have also been shown to be related to cell metastasis (40-42). Moreover, the protein level of uPA was reduced by KT2. uPA, a serine protease, cleaves plasminogen to plasmin, which is able to promote cancer cell proliferation and angiogenesis, degrade the ECM and basement membrane, and activate pro-MMPs (43). The reduction of uPA can inhibit MMP activity and improve antiinvasion activity (40). However, KT2 up-regulated PI3K but did not significantly change PKC and MMP-9. Hence, further examinations are warranted.
The possible strengths of this study, KT2 peptide is derived from a natural product, good cell penetration, high specificity to cancer cells, and low toxicity against normal cells (25). In this manuscript, we firstly showed that KT2 suppressed the cell viability, cell migration and cell invasion of A375.S2 melanoma cells. It also had a good cell-penetrating ability. Further investigations including the elucidation of other molecular mechanisms, the exploration of its combination with chemotherapy, and in vivo study should be performed. Prediction of peptide binding sites on cell surfaces and/or intracellular target will help elicidate more details about the mechanism of action of the KT2 peptide.

\section{Conclusion}

Taken together, sufficient evidence at the cellular and molecular levels, support claims that the anti-cancer peptide KT2 could inhibit cancer cell metastasis by exhibiting an inhibitory effect on FAK, RhoA, ROCK1, GRB2, SOS-1, pJNK, p-c-Jun, PI3K, p-AKT (Thr308), p-AKT (Ser473), pp38, NF-kB, and uPA by down-regulating MMP-2 and -9 and then inhibiting the invasion and migration of A375.S2 cells (Figure 7). The study provides a rationale for using KT2 as a potential agent for the treatment of metastatic melanoma.

\section{Conflicts of Interest}

The Authors declare that there are no conflicts of interest.

\section{Authors' Contributions}

Conceptual framework: J.D., S.K., and J.-G.C. Experimental design: P.M. and S.-F. P. The core facility for materials and analysis tools: J.-G.C. and S.-F. P. Performing experiments: P.M., S.D., and P.R. Data analysis and result interpretations: P.M., R.T., and P.B. Drafting manuscript: P.M. Revising manuscript: S.-F. P., J.D., and J.-G.C. Final approval version of the manuscript: J.D.

\section{Acknowledgements}

This work was supported by The Royal Golden Jubilee (RGJ) Ph.D. Scholarship (PHD/0014/2558), Khon Kaen University (grant no. 61004605), and the Centre for Research and Development of Medical Diagnostic Laboratories, Faculty of Associated Medical Sciences and Post-Doctoral Training Program from Research and Technology Transfer Affairs, Khon Kaen University (KKU) and Graduate School, KKU, Thailand (grant no. 583334). The authors would like to thank Professor Jing-Gung Chung of the Department of Biological Science and Technology, China Medical University, Taichung, Taiwan for the experimental facilities and support.

\section{References}

1 Guan X: Cancer metastases: Challenges and opportunities. Acta Pharm Sin B 5(5): 402-418, 2015. PMID: 26579471. DOI: 10.1016/j.apsb.2015.07.005 
2 Seyfried TN and Huysentruyt LC: On the origin of cancer metastasis. Crit Rev Oncog 18(1-2): 43-73, 2013. PMID: 23237552. DOI: $10.1615 /$ critrevoncog.v18.i1-2.40

3 Gandalovicova A, Rosel D, Fernandes M, Vesely P, Heneberg P, Cermak V, Petruzelka L, Kumar S, Sanz-Moreno V and Brabek J: Migrastatics-anti-metastatic and anti-invasion drugs: Promises and challenges. Trends Cancer 3(6): 391-406, 2017. PMID: 28670628. DOI: 10.1016/j.trecan.2017.04.008

4 Treasure T: Surgery and ablative techniques for lung metastases in the pulmonary metastasectomy in colorectal cancer (PulMiCC) trial: Is there equivalence? J Thorac Dis 8(Suppl 9): S649-S651, 2016. PMID: 28066664. DOI: $10.21037 /$ jtd.2016.06.50

5 Li D, Kang J, Golas BJ, Yeung VW and Madoff DC: Minimally invasive local therapies for liver cancer. Cancer Biol Med 11(4): 217-236, 2014. PMID: 25610708. DOI: 10.7497/j.issn.20953941.2014.04.001

6 Chen MT, Sun HF, Zhao Y, Fu WY, Yang LP, Gao SP, Li LD, Jiang HL and Jin W: Comparison of patterns and prognosis among distant metastatic breast cancer patients by age groups: A SEER population-based analysis. Sci Rep 7(1): 9254, 2017. PMID: 28835702. DOI: 10.1038/s41598-017-10166-8

7 Siegel RL, Miller KD and Jemal A: Cancer statistics, 2016. CA Cancer J Clin 66(1): 7-30, 2016. PMID: 26742998. DOI: $10.3322 /$ caac. 21332

8 Velho TR: Metastatic melanoma-a review of current and future drugs. Drugs Context 2012: 212242, 2012. PMID: 24432031. DOI: $10.7573 /$ dic. 212242

9 Wrobel LJ and Le Gal FA: Inhibition of human melanoma growth by a non-cardioselective beta-blocker. J Invest Dermatol 135(2): 525-531, 2015. PMID: 25178102. DOI: $10.1038 /$ jid.2014.373

10 Balch CM, Gershenwald JE, Soong SJ, Thompson JF, Atkins MB, Byrd DR, Buzaid AC, Cochran AJ, Coit DG, Ding S, Eggermont AM, Flaherty KT, Gimotty PA, Kirkwood JM, McMasters KM, Mihm MC, Jr., Morton DL, Ross MI, Sober AJ and Sondak VK: Final version of 2009 AJCC melanoma staging and classification. J Clin Oncol 27(36): 6199-6206, 2009. PMID: 19917835. DOI: 10.1200/JCO.2009.23.4799

11 Yavari B, Mahjub R, Saidijam M, Raigani M and Soleimani M: The potential use of peptides in cancer treatment. Curr Protein Pept Sci 19(8): 759-770, 2018. PMID: 29332577. DOI: $10.2174 / 1389203719666180111150008$

12 Bruno BJ, Miller GD and Lim CS: Basics and recent advances in peptide and protein drug delivery. Ther Deliv 4(11): 14431467, 2013. PMID: 24228993. DOI: 10.4155/tde.13.104

13 Marqus S, Pirogova E and Piva TJ: Evaluation of the use of therapeutic peptides for cancer treatment. J Biomed Sci 24(1): 21, 2017. PMID: 28320393. DOI: 10.1186/s12929-017-0328-x

14 Tu Z, Volk M, Shah K, Clerkin K and Liang JF: Constructing bioactive peptides with pH-dependent activities. Peptides 30(8): 1523-1528, 2009. PMID: 19464332. DOI: 10.1016/j.peptides.2009. 05.009

15 Jin L, Bai X, Luan N, Yao H, Zhang Z, Liu W, Chen Y, Yan X, Rong M, Lai $\mathrm{R}$ and $\mathrm{Lu} \mathrm{Q}: \mathrm{A}$ designed tryptophan- and lysine/arginine-rich antimicrobial peptide with therapeutic potential for clinical antibiotic-resistant Candida albicans vaginitis. J Med Chem 59(5): 1791-1799, 2016. PMID: 26881456. DOI: 10.1021/acs.jmedchem.5b01264

16 Zhang P, Ma J, Yan Y, Chen B, Liu B, Jian C, Zhu B, Liang S, Zeng Y and Liu Z: Arginine modification of lycosin-I to improve inhibitory activity against cancer cells. Org Biomol Chem 15(44): 9379-9388, 2017. PMID: 29090725. DOI: 10.1039/c7ob02233f

17 Jobin ML, Blanchet M, Henry S, Chaignepain S, Manigand C, Castano S, Lecomte S, Burlina F, Sagan S and Alves ID: The role of tryptophans on the cellular uptake and membrane interaction of arginine-rich cell penetrating peptides. Biochim Biophys Acta 1848(2): 593-602, 2015. PMID: 25445669. DOI: 10.1016/j.bbamem.2014.11.013

18 Zhang SK, Song JW, Gong F, Li SB, Chang HY, Xie HM, Gao HW, Tan YX and Ji SP: Design of an alpha-helical antimicrobial peptide with improved cell-selective and potent anti-biofilm activity. Sci Rep 6: 27394, 2016. PMID: 27271216. DOI: 10.1038/srep27394

19 Papo N, Seger D, Makovitzki A, Kalchenko V, Eshhar Z, Degani $\mathrm{H}$ and Shai Y: Inhibition of tumor growth and elimination of multiple metastases in human prostate and breast xenografts by systemic inoculation of a host defense-like lytic peptide. Cancer Res 66(10): 5371-5378, 2006. PMID: 16707464. DOI: 10.1158/0008-5472.CAN-05-4569

20 Lee MW, Bassiouni R, Sparrow NA, Iketani A, Boohaker RJ, Moskowitz C, Vishnubhotla P, Khaled AS, Oyer J, Copik A, Fernandez-Valle C, Perez JM and Khaled AR: The CT20 peptide causes detachment and death of metastatic breast cancer cells by promoting mitochondrial aggregation and cytoskeletal disruption. Cell Death Dis 5(5): e1249, 2014. PMID: 24853427. DOI: $10.1038 /$ cddis.2014.225

21 Bi Z, Liu W, Ding R, Wu Y, Dou R, Zhang W, Yuan X, Liu X, Xiong L, Guo Z and Mao C: A novel peptide, 9R-P201, strongly inhibits the viability, proliferation and migration of liver cancer HepG2 cells and induces apoptosis by down-regulation of FoxM1 expression. Eur J Pharmacol 796: 175-189, 2017. PMID: 28012972. DOI: 10.1016/j.ejphar.2016.12.029

22 Anunthawan T, Yaraksa N, Phosri S, Theansungnoen T, Daduang $\mathrm{S}$, Dhiravisit $\mathrm{A}$ and Thammasirirak $\mathrm{S}$ : Improving the antibacterial activity and selectivity of an ultra short peptide by hydrophobic and hydrophilic amino acid stretches. Bioorg Med Chem Lett 23(16): 4657-4662, 2013. PMID: 23831136. DOI: 10.1016/j.bmcl.2013.06.005

23 Theansungnoen T, Maijaroen S, Jangpromma N, Yaraksa N, Daduang $\mathrm{S}$, Temsiripong $\mathrm{T}$, Daduang $\mathrm{J}$ and Klaynongsruang $\mathrm{S}$ : Cationic antimicrobial peptides derived from Crocodylus siamensis leukocyte extract, revealing anticancer activity and apoptotic induction on human cervical cancer cells. Protein J 35(3): 202-211, 2016. PMID: 27129462. DOI: 10.1007/s10930016-9662-1

24 Maraming P, Klaynongsruang S, Boonsiri P, Peng SF, Daduang $\mathrm{S}$, Leelayuwat $\mathrm{C}$, Pientong $\mathrm{C}$, Chung JG and Daduang J: The cationic cell-penetrating KT2 peptide promotes cell membrane defects and apoptosis with autophagy inhibition in human HCT 116 colon cancer cells. J Cell Physiol 234(12): 22116-22129, 2019. PMID: 31073999 . DOI: $10.1002 /$ jcp. 28774

25 Maijaroen S, Jangpromma N, Daduang J and Klaynongsruang S: KT2 and RT2 modified antimicrobial peptides derived from Crocodylus siamensis Leucrocin I show activity against human colon cancer HCT-116 cells. Environ Toxicol Pharmacol 62: 164 176, 2018. PMID: 30031283. DOI: 10.1016/j.etap.2018.07.007

26 Maraming P, Maijaroen S, Klaynongsruang S, Boonsiri P, Daduang S, Chung JG and Daduang J: Antitumor ability of KT2 peptide derived from leukocyte peptide of crocodile against human HCT116 colon cancer xenografts. In Vivo 32(5): 11371144, 2018. PMID: 30150436. DOI: 10.21873/invivo.11356 
27 Juan TK, Liu KC, Kuo CL, Yang MD, Chu YL, Yang JL, Wu PP, Huang YP, Lai KC and Chung JG: Tetrandrine suppresses adhesion, migration and invasion of human colon cancer SW620 cells via inhibition of nuclear factor-kB, matrix metalloproteinase-2 and matrix metalloproteinase-9 signaling pathways. Oncol Lett 15(5): 7716-7724, 2018. PMID: 29731901. DOI: $10.3892 / \mathrm{ol} .2018 .8286$

28 Patathananone S, Thammasirirak S, Daduang J, Gung Chung J, Temsiripong $\mathrm{Y}$ and Daduang S: Inhibition of HeLa cells metastasis by bioactive compounds in crocodile (Crocodylus siamensis) white blood cells extract. Environ Toxicol 31(11): 1329-1336, 2016. PMID: 25855086. DOI: 10.1002/tox.22138

$29 \mathrm{Wu}$ ZY, Lien JC, Huang YP, Liao CL, Lin JJ, Fan MJ, Ko YC, Hsiao YP, Lu HF and Chung JG: Casticin inhibits A375.S2 human melanoma cell migration/invasion through downregulating NF-kB and matrix metalloproteinase-2 and -1 . Molecules 21(3): 384, 2016. PMID: 27007357. DOI: $10.3390 /$ molecules 21030384

30 Deslouches B and Di YP: Antimicrobial peptides with selective antitumor mechanisms: Prospect for anticancer applications. Oncotarget 8(28): 46635-46651, 2017. PMID: 28422728. DOI: 10.18632/oncotarget.16743

31 Lehmann J, Retz M, Sidhu SS, Suttmann H, Sell M, Paulsen F, Harder J, Unteregger G and Stockle M: Antitumor activity of the antimicrobial peptide magainin II against bladder cancer cell lines. Eur Urol 50(1): 141-147, 2006. PMID: 16476519. DOI: $10.1016 /$ j.eururo.2005.12.043

32 Boohaker RJ, Lee MW, Vishnubhotla P, Perez JM and Khaled AR: The use of therapeutic peptides to target and to kill cancer cells. Curr Med Chem 19(22): 3794-3804, 2012. PMID: 22725698. DOI: 10.2174/092986712801661004

33 Sun CM, Shen WC, Tu JS and Zaro JL: Interaction between cellpenetrating peptides and acid-sensitive anionic oligopeptides as a model for the design of targeted drug carriers. Mol Pharm 11(5): 1583-1590, 2014. PMID: 24697211. DOI: 1 10.1021/mp400747k

34 Anunthawan T, de la Fuente-Nunez C, Hancock REW and Klaynongsruang S: Cationic amphipathic peptides KT2 and RT2 are taken up into bacterial cells and kill planktonic and biofilm bacteria. Biochim Biophys Acta 1848(6): 1352-1358, 2015. PMID: 25767037. DOI: 10.1016/j.bbamem.2015.02.021

35 Friedl $\mathrm{P}$ and Wolf K: Tumour-cell invasion and migration: diversity and escape mechanisms. Nat Rev Cancer 3(5): 362374, 2003. PMID: 12724734. DOI: 10.1038/nrc1075
36 Chuang CH, Wang LY, Wong YM and Lin ES: Anti-metastatic effects of isolinderalactone via the inhibition of MMP-2 and upregulation of $\mathrm{NM}_{23}-\mathrm{H} 1$ expression in human lung cancer A549 cells. Oncol Lett 15(4): 4690-4696, 2018. PMID: 29541242. DOI: $10.3892 / \mathrm{ol} .2018 .7862$

37 Sulzmaier FJ, Jean C and Schlaepfer DD: FAK in cancer: Mechanistic findings and clinical applications. Nat Rev Cancer 14(9): 598-610, 2014. PMID: 25098269. DOI: 10.1038/nrc3792

38 Kamai T, Tsujii T, Arai K, Takagi K, Asami H, Ito Y and Oshima $\mathrm{H}$ : Significant association of Rho/Rock pathway with invasion and metastasis of bladder cancer. Clin Cancer Res 9(7): 26322641, 2003. PMID: 12855641.

39 Zhang JB, He X, Ma YY, Liu YL, Shi HY, Guo WW and Liu LF: Overexpression of ROCK1 and ROCK2 inhibits human laryngeal squamous cell carcinoma. Int J Clin Exp Pathol 8(1): 244-251, 2015. PMID: 25755711.

$40 \mathrm{Wu}$ YJ, Neoh CA, Tsao CY, Su JH and Li HH: Sinulariolide suppresses human hepatocellular carcinoma cell migration and invasion by inhibiting matrix metalloproteinase-2/-9 through MAPKs and PI3K/Akt signaling pathways. Int J Mol Sci 16(7): 16469-16482, 2015. PMID: 26204832. DOI: 10.3390/ijms 160716469

41 Yan M, Xu Q, Zhang P, Zhou XJ, Zhang ZY and Chen WT: Correlation of NF-kappa B signal pathway with tumor metastasis of human head and neck squamous cell carcinoma. BMC Cancer 10: 437, 2010. PMID: 20716363. DOI: 10.1186/1471-2407-10-437

$42 \mathrm{Lv}$ T, Zhang WJ and Han XL: Zerumbone suppresses the potential of growth and metastasis in hepatoma HepG2 cells via the MAPK signaling pathway. Oncol Lett 15(5): 7603-7610, 2018. PMID: 29849796. DOI: 10.3892/ol.2018.8335

43 Roomi MW, Kalinovsky T, Niedzwiecki A and Rath M: Modulation of uPA, MMPs and their inhibitors by a novel nutrient mixture in human colorectal, pancreatic and hepatic carcinoma cell lines. Int J Oncol 47(1): 370-376, 2015. PMID: 25997494. DOI: $10.3892 /$ ijo.2015.3008

Received September 20, 2020

Revised October 5, 2020

Accepted October 7, 2020 